\title{
LA PRUDENCIA EN DESCARTES
}

$\mathrm{M}^{\mathrm{a}}$ Victoria Castellón Masalles

Esta comunicación quiere ser una reflexión sobre la prudencia. entendiendo que en Descartes es un rasgo de estilo. Algo que le acompaiaba en su pensar, incluso como método; aunque ello sea a veces debido a motivos exteriores a él. Su pensar, esta prudencia, -que es un modo de acción-puede acompañamos ahora, ya que el pensar y el actuar se nos han puesto dificiles.

Descartes entiende al entendimiento y a la voluntad como dos facultades distintas del hombre, y nos dice que: "la luz natural nos enseña que el conocimiento del entendimiento debe siempre preceder a la determinación de la voluntad". Asi, cuando afirma que: "no es suficiente tener buen sentido, sino que lo principal es aplicarlo bien", vemos, como entre entendimiento y voluntad (la determinación aplicada a la acción) se alza algo imperceptible pero necesario para que la consecución del resultado sea bueno: la prudencia.

El tratamiento que Nietzsche hace de la voluntad es radicalmente distinto. Para él la voluntad sólo posee "unidad verbal" pues la entiende como pugna de fuerzas o instintos, cuya resultante denomina "afecto de mando", es decir "voluntad de poder". Ejemplo de ella la tenemos en la propia trayectoria del pensamiento occidental, y de ella nos dice: "A mi la volición me parece ante todo algo complicado, algo que solo como palabra forma una unidad".

Al no reencontrarse Nietzsche con un "cogito" sino con muchas almas o muchos "yos" y al identificarlos a fuerzas o instintos, la voluntad se le presenta como el resultado de una pugna por la supervivencia animica. Algo que le lleva en sus formas exacerbadas a proyectar su "modo de estar" —nervado—al mundo mismo. Y eso, bajo sus ojos, como Nietzsche lo mira, y más que ver al mundo lo que ve es la vida. Vida que quiere expresarse y que lo hace en forma agonistica. Lucha como expresión de existencia.

Pero, al destruir la sustancia pensante cartesiana, Nietzsche rompe el suelo bajo sus pies. Construir a partir de ella o al menos laber rebajado su propia audacia contribuye a adquirir una cierta prudencia, que en el decir de Descartes es "....pues siempre que contengo mi voluntad en los limites de mi conocimiento... es imposible que me engañe".

Las vivencias y los estados de ánimo de ámbos filósofos son distintos. Por ejemplo el "horror" que delecta Descartes lo siente según nos dice "al pisar una hoja seca" o "a un gusano". El horror al que se enfrenta Nietzsche se le abre desde dentro, le desgarra, le aniquila. También Descartes aniquiló y aniquiló mucho. Rompió. Ya no tue Dios el punto de salida, fue el "cogito". Y Nietzsclee, de un plumazo, sin dar inuclio más terreno que a "agujeros negros", intensidades, -muchas de ellas aniquiladoras-, de abolición, de muerte del propio sujeto; aniquila un terreno en el que con su critica a la razón - pero más trabajada, más construida, al modo de la tenacidad de un Spinoza o un Marx- hubiera evitado quizás sufrimiento al "yo".

Como le dijo Colli a Nietzsche; ¿por qué no eres más griego?.

No es la contundencia la forma de hablar de la razón, sino la constancia, el trabajo y el mantener algo, por leve que sea a flote. Porque, el aniquilarnos como sujetos, otros nos sujetan; como bien debió entreverlo Nietzsche en sus últinıos años de locura.

$Y$ dado que la locura es sufrimiento y pavor y no sólo exuberancia dionisiaca (esa tragedia que él ya comenzó a entrever en su primera obra) entonces: ¿por qué no construirle al hombre algo que sea menor que dios o menor que el superhombre?, pues, como bien dice Descirtes "es pro de la naturaleza de lo intinito que yo siendo finito, no pueda comprenderlo". 
Nietzsche nos propone mera voluntad, mera resultante de intensidades, impulsos e instintos, en cuanto que la razón es para è —aunque bien la ejerce en su vertiente crítica- negadora y aniquiladora de la vida. Sin embargo la razón también sosiega y nos permite distinguir "...pues siempre que contengo mi voluntad en los limites de mi conocimiento... es imposible que me engañe...".

A lo mejor eso no es del todo cierto, quizas la prudencia cartesiana es excesiva y confiada; pero cuando lo leemos nos frena el pavor y nos reconduce el miedo a ciertos lugares habitables para el entendimiento y para el mismo afecto.

Vencer al miedo no es vencer al sufrimiento y no por ello es tener razón; pero porque no somos infinitos queremos reclamarla.

Dice Descartes "Tras esto, viniendo a mi propio e indagando en mis errores (...) hallo que dependen del concurso de dos causas, a saber: de mi facultad de elegir $\longrightarrow$ sea, mi libre arbitrio-; esto es de mi entendimiento y de mi voluntad".

Desde esta perspectiva podriamos leer el " cogito" como la construcción de un plano de consistencia -en cierta manera provisional-, un lugar que para nosotros hoy', parece brindarnos un hueco en nosotros mismos, desde el cual pensar, dudar, y desear; $y$ así poder llegar a decir junto a Descartes que el "cogito" es un pensamiento que actúa, ya que "lo que para el alma es una pasión, para el cuerpo se convierte en acción". 